\title{
GLJIVAMA SLIČNI ORGANIZMI U TLU ODUMIRUĆIH SASTOJINA POLJSKOG JASENA (Fraxinus angustifolia VAHL)
}

\section{FUNGUS-LIKE ORGANISMS IN THE SOIL OF DECLINING NARROW-LEAVED ASH STANDS (Fraxinus angustifolia Vahl)}

\author{
Jelena KRANJEC ${ }^{1}$, Marno MILOTIĆ ${ }^{1}$, Marija HEGOL², Danko DIMINIĆ1
}

\begin{abstract}
Sažetak
Poljski jasen (Fraxinus angustifolia Vahl) je trenutno jedna od najugroženijih vrsta drveća u Republici Hrvatskoj, pokazujući znatno pogoršanje zdravstvenog stanja u posljednjih nekoliko godina. Dosadašnjim je istraživanjima mogućih biotskih uzročnika na nadzemnim dijelovima stabala potvrđena prisutnost patogene gljive Hymenoscyphus fraxineus Baral, Queloz \& Hosoya na nekoliko različitih lokacija. Kako bi se utvrdilo postoje li potencijalni biotski čimbenici koji utječu na odumiranje i u podzemnom dijelu sastojina, ovim je istraživanjem izvršena analiza prisutnosti gljivama sličnih organizama u tlu četiri sastojine sa simptomima odumiranja, s naglaskom na traženje vrsta roda Phytophthora koje su poznate kao patogeni šumskog drveća. Indirektnim metodama izolacije dobivena su 24 izolata gljivama sličnih organizama u ukupno 30 uzoraka tla, od kojih je njih šest identificirano do razine vrste primjenom molekularnih metoda. Rezultati nisu potvrdili prisutnost patogenih vrsta roda Phytophthora, već su pokazali da izolirane vrste pripadaju rodovima Pythium i Phytopythium. Iako su vrste navedenih rodova poznate kao patogeni određenih poljoprivrednih kultura i šumskih sadnica u rasadnicima, te često i u velikoj mjeri prisutne u tlima odumirućih šumskih sastojina, za sada se ne može sa sigurnošću potvrditi njihova uloga u procesu odumiranja.
\end{abstract}

KLJUČNE RIJEČI: poljski jasen, gljivama slični organizmi, tlo, Pythium, Phytopythium

\section{UVOD}

\section{INTRODUCTION}

Poljski jasen (Fraxinus angustifolia Vahl), gospodarski i ekološki vrlo značajna vrsta nizinskih šuma Hrvatske, posljednjih nekoliko godina pokazuje sve izraženije simptome odumiranja. Prema procjeni oštećenosti krošanja koja se u Hrvatskoj provodi svake godine u sklopu međunarodnog programa ICP Forests, udio značajno osutih stabala poljskog jasena (osutost veća od $25 \%$ ) je u 2014. godini narastao s 23,61 na 49,09\% u odnosu na prethodnu godinu, te se u 2015. nastavio povećavati do 62,50 \% (Potočić i sur. 2016). Dosadašnja istraživanja mogućih uzroka odumiranja bila su usmjerena na nadzemne dijelove stabala te su potvrdila prisutnost patogene gljive Hymenoscyphus fraxineus Baral, Queloz \& Hosoya na više različitih lokacija na stablima narušenog zdravstvenog stanja u Hrvatskoj (Diminić 2015, Milotić i sur. 2016), a zaraza poljskog jasena navedenim patogenom

\footnotetext{
1Jelena Kranjec, mag. ing. silv., jkranjec@sumfak.hr; dr. sc. Marno Milotić, mmilotic@sumfak.hr; prof. dr. sc. Danko Diminić, ddiminic@sumfak.hr, Sveučilište u Zagrebu, Šumarski fakultet, Zavod za zaštitu šuma i lovno gospodarenje, Svetošimunska 25, 10002 Zagreb, Hrvatska

${ }^{2}$ Marija Hegol, mag. ing. silv., marija.hegol@gmail.com, Vinogradska 11, 10312 Kloštar Ivanić, Hrvatska
} 
potvrđena je i u Češkoj (Jankovsky i Holdenrieder 2009), Austriji (Kirisits i sur. 2010) te Sloveniji (Hauptman i sur. 2012). Kako je odumiranje šumskih sastojina posljedica kumulativnog i sinergijskog djelovanja više različitih abiotskih i biotskih čimbenika, istraživanja koja se provode s ciljem pronalaženja uzroka su sveobuhvatna, te osim pregleda nadzemnog dijela oboljelih stabala često uključuju i pretraživanje podzemnog dijela, to jest, korijenovog sustava i tla. Pritom se prisutnost gljivama sličnih organizama, s naglaskom na patogene vrste roda Phytophthora, smatra važnim biotskim čimbenikom odgovornim za smrtnost stabala (Jankowiak i sur. 2014).

Gljivama slični organizmi (Oomycetes) predstavljaju raznoliku skupinu eukariota koji su dugo vremena smatrani gljivama, a uključuju saprotrofe i patogene biljaka i životinja te ostale različite mikroorganizme (Margulis i Schwartz 2000). U odumiranju nekih od najvažnijih vrsta šumskog drveća u Europi sudjeluju gljivama slični organizmi roda Phytophthora (Jung i sur. 2013), dok su vrste roda Pythium poznate kao kozmopolitske vrste sveprisutne u tlu, od kojih su nekolicina potvrđene kao biljni patogeni koji mogu uzrokovati polijeganje ponika, ali i trulež plodova, sjemena, korijena i debla šumskih vrsta drveća ponajprije u rasadnicima (Campbell i sur. 1972, Jankowiak i sur. 2015). Vrste roda Pythium koje su pripadale kladi K (Lévesque i de Cock 2004) u novije vrijeme su zbog značajki koje dijele s vrstama roda Phytophthora svrstane u novi rod Phytopythium (Bala i sur. 2010, de Cock i sur. 2015), a autori navode kako i u ostalim kladama (A-J) može doći do sličnih promjena, iako preporučuju korištenje dosadašnje podjele dok se ne nađu odgovarajući filogenetski biljezi (de Cock i sur. 2015).

U Europi je do sada provedeno nekoliko istraživanja usmjerenih na identifikaciju gljivama sličnih organizama u tlu šumskih sastojina te njihovu potencijalnu ulogu u procesu odumiranja. U sastojinama hrasta lužnjaka (Quercus robur L.) različitog zdravstvenog stanja je u Njemačkoj (Jung i sur. 2000), Italiji (Vettraino i sur. 2002), Švedskoj (Jönsson i sur. 2003), Austriji (Balcì i Halmschlager 2003a), Turskoj (Balcì i Halmschlager 2003b) i Poljskoj (Jankowiak i sur. 2014) utvrđeno kako postoji određena povezanost pronađenih vrsta roda Phytophthora u tlu i zdravstvenog statusa stabala. Slična istraživanja provedena u sastojinama sa simptomima odumiranja u Poljskoj i Danskoj na običnom jasenu (Fraxinus excelsior L.) (Orlikowski i sur. 2011) te u Turskoj na poljskom jasenu (Akilli i sur. 2013) potvrdila su prisutnost vrsta roda Phytophthora u tlu, te uputila na njihovo sudjelovanje u procesu odumiranja stabala.

Dio do sada provedenih istraživanja usmjerenih ponajprije na identifikaciju vrsta roda Phytophthora, također opisuje prisutnost vrsta rodova Pythium i Phytopythium u šumskim tlima, ali bez potvrde njihovog utjecaja na zdravstveno stanje stabala (Jung i sur. 2000, Jönsson i sur. 2003, Balcì i Halmschlager 2003a, Balcì i Halmschlager 2003b, Jankowiak i sur.
2015). Osim u tlu, vrste rodova Phytophthora i Pythium identificirane su u riječnim tokovima u blizini zaraženih šumskih područja u Poljskoj i Ukrajini (Matsiakh i sur. 2016).

U Hrvatskoj su preliminarna testiranja pomoću terenskih dijagnostičkih testova (eng. Pocket diagnostic test, Abingdon Health Ltd., UK) za dokazivanje prisutnosti vrsta roda Phytophthora u biljnom tkivu pokazala pozitivne rezultate na uzorcima tla u odumirućim sastojinama poljskog jasena na području Posavine (Hegol 2016). Kako su navedeni rezultati općenitog karaktera te ne pružaju dodatne informacije o samim vrstama, svrha ovog istraživanja bila je utvrditi prisutnost gljivama sličnih organizama u tlu sastojina poljskog jasena, koje pokazuju simptome odumiranja metodama koje uključuju izolaciju i identifikaciju vrsta, s ciljem da se potvrdi ili odbaci hipoteza kako patogene vrste iz roda Phytophthora imaju potencijalnu ulogu u odumiranju stabala. Osim toga, namjera je bila dati doprinos poznavanju bioraznolikosti gljivama sličnih organizama u tlu šumskih ekosustava Republike Hrvatske, o čemu do sada postoji vrlo malen broj zapisa.

\section{MATERIJALI I METODE MATERIALS AND METHODS}

\section{Uzorkovanje tla na terenu - Soil sampling in the field}

Uzorkovanja tla obavljena su tijekom listopada i studenog 2016. godine na četiri različite lokacije u sastojinama poljskog jasena u kojima postoji problem odumiranja. Lokacije uzorkovanja obuhvatile su GJ Josip Kozarac na području šumarije Lipovljani, GJ Črnovščak na području šumarije Dugo Selo te GJ Trstika na području šumarije Novska. Tlo se sakupljalo oko stabala svrstanih u tri kategorije zdravstvenog stanja procijenjenog na temelju stupnja osutosti krošnje određenog prema teoretskom referentnom stablu. U zdrava stabla su svrstana ona s osutošću krošnje manjom ili jednakom $25 \%$, u stabla narušenog zdravstvenog stanja ona s osutošću od 26 do $60 \%$, dok su stabla osutosti od 61 do $99 \%$ kategorizirana kao odumiruća (tablica 1). Odumrla stabla se nisu uzimala u obzir. U svakoj je gospodarskoj jedinici uzorkovano tlo oko 10 stabala iskapanjem po tri monolita tla zajedno sa sitnim korijenjem približnih dimenzija $25 \times 25 \times 25 \mathrm{~cm}$ (bez listinca i humusa) na tri različite točke na rubu projekcije krošnje, odnosno na udaljenosti 0,5 - 1 m od debla, ovisno o promjeru krošnje svakog istraživanog stabla. Tri su uzorka homogenizirana u jedan, od kojeg se za daljnje laboratorijske analize uzimao poduzorak volumena približno dvije litre (Jankowiak i sur. 2014).

\section{Laboratorijska analiza uzoraka - metoda potapanja tla - Laboratory analysis of samples - soil flooding method}

Za laboratorijsku obradu uzoraka tla korištena je prilagođena metoda prema Themann i Werres (1999). U razdoblju od $24 \mathrm{~h}$ od vremena sakupljanja, po $250 \mathrm{ml}$ svakog uzorka 
Tablica 1. Lokacije uzorkovanja i zdravstveno stanje uzorkovanih stabala Table 1. Sampling locations and health status of sampled trees

\begin{tabular}{|c|c|c|}
\hline $\begin{array}{l}\text { Lokacija } \\
\text { Location }\end{array}$ & 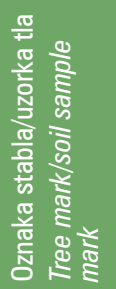 & 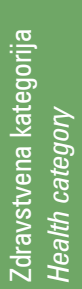 \\
\hline \multirow{10}{*}{$\begin{array}{l}\text { Dugo Selo, GJ Črnovščak, } 16 \mathrm{~g} \\
\text { Mješovita sastojina poljskog jasena i crne johe } \\
\text { nastala iz sjemena i panja, starosti } 30 \text { godina } \\
\text { Mixed narrow-leaved ash and black alder stand } \\
\text { from seed and stump sprouts, } 30 \text { years old }\end{array}$} & 4 & 3 \\
\hline & 6 & 3 \\
\hline & 7 & 2 \\
\hline & 8 & 1 \\
\hline & 16 & 1 \\
\hline & 17 & 1 \\
\hline & 18 & 1 \\
\hline & 20 & 2 \\
\hline & 27 & 2 \\
\hline & 28 & 1 \\
\hline \multirow{3}{*}{$\begin{array}{l}\text { Lipovljani, GJ Josip Kozarac, 80a } \\
\text { Čista sastojina poljskog jasena nastala } \\
\text { iz sjemena, starosti } 45 \text { godina }\end{array}$} & 41 & 2 \\
\hline & 42 & 2 \\
\hline & 43 & 3 \\
\hline \multirow{2}{*}{$\begin{array}{l}\text { Pure narrow-leaved ash stand from seed, } \\
45 \text { years old }\end{array}$} & 44 & 3 \\
\hline & 45 & 3 \\
\hline \multirow{3}{*}{$\begin{array}{l}\text { Lipovljani, GJ Josip Kozarac, 71d } \\
\text { Čista sastojina poljskog jasena nastala } \\
\text { iz sjemena, starosti } 30 \text { godina }\end{array}$} & 51 & 2 \\
\hline & 52 & 1 \\
\hline & 54 & 1 \\
\hline \multirow{2}{*}{$\begin{array}{l}\text { Pure narrow-leaved ash stand from seed, } \\
30 \text { years old }\end{array}$} & 56 & 2 \\
\hline & 58 & 3 \\
\hline \multirow{10}{*}{$\begin{array}{l}\text { Novska, GJ Trstika, } 37 \mathrm{~b} \\
\text { Čista sastojina poljskog jasena nastala } \\
\text { iz sjemena, starosti } 25 \text { godina } \\
\text { Pure narrow-leaved ash stand from seed, } \\
25 \text { years old }\end{array}$} & 76 & 1 \\
\hline & 77 & 2 \\
\hline & 78 & 3 \\
\hline & 79 & 1 \\
\hline & 80 & 2 \\
\hline & 86 & 1 \\
\hline & 87 & 2 \\
\hline & 88 & 3 \\
\hline & 89 & 2 \\
\hline & 90 & 3 \\
\hline
\end{tabular}

Legenda: Zdravstvena kategorija: 1-zdrava stabla osutosti krošnje $\leq 25 \%$, 2-stabla narušenog zdravstvenog stanja osutosti krošnje 26-60 \%, 3-odumiruća stabla osutosti krošnje 61-99 \%

Legend: Health category: 1-healthy trees with crown defoliation $\leq 25 \%$, 2-trees having impaired health status with crown defoliation of $26-60 \%$, 3-declining trees with crown defoliation of $61-99 \%$

tla ravnomjerno je raspoređeno u plastične posude dimenzija $23,5 \times 15 \times 5 \mathrm{~cm}$ te potopljeno ultračistom vodom $(0,055$ $\mu \mathrm{S} / \mathrm{cm}$ ) volumena $500 \mathrm{ml}$, tako da je površina vode bila 1 do $2 \mathrm{~cm}$ iznad površine tla. Ovako pripremljeni uzorci ostavljali su se tri dana na sobnoj temperaturi $\left(18-22^{\circ} \mathrm{C}\right) \mathrm{u}$ poklopljenim posudama (Vettraino i sur. 1999), nakon čega se na površinu vode postavljalo 3 do 5 razvijenih i svježe ubranih listova vrsta Rhododendron catawbiense Michx. i
Prunus laurocerasus L. Listovi su prethodno oprani vodom iz slavine, uz lagano četkanje kako bi se uklonile veće nečistoće te zatim kratko isprani u sterilnoj vodi (sterilizacija u autoklavu na $121^{\circ} \mathrm{C}, 20 \mathrm{~min}$ ) i ostavljeni da se u potpunosti osuše unutar laminarnog kabineta za rad u atmosferi čistog zraka. Posude s postavljenim listovima su se lagano zaklopljene ostavljale na sobnoj temperaturi i prirodnom režimu svjetlosti 2 do 8 dana, odnosno do pojave prvih simptoma infekcije gljivama sličnih organizama na lišću (kloroza i nekroza).

\section{Izolacija gljivama sličnih organizama iz simptomatičnih listova - Isolation of fungal-like organisms from symptomatic leaves}

Za izolacije gljivama sličnih organizama iz simptomatičnih listova pripremljene su hranjive podloge $10 \%$ CJA (Carrot Juice Agar, sok mrkve iz biološkog uzgoja, dmBIO Karottensaft) te $10 \%$ VJA (Vegetable Juice Agar, povrtni sok iz biološkog uzgoja, Biotta Breuss). Za pripremu 1 litre navedenih podloga je u $100 \mathrm{ml}$ soka dodan $1 \mathrm{~g}$ kalcijevog karbonata $\left(\mathrm{CaCO}_{3}\right)$ uz stalno miješanje na $150{ }^{\circ} \mathrm{C}$ u trajanju od 20 minuta, te zatim $900 \mathrm{ml}$ destilirane vode i $15 \mathrm{~g}$ agaragara, uz stalno miješanje na $250^{\circ} \mathrm{C}$ u trajanju od približno 30 minuta (Jeffers 2007). Prije izlijevanja u sterilne Petrijeve zdjelice, hranjive su podloge sterilizirane u autoklavu 20 minuta na $121^{\circ} \mathrm{C}$, te je u njih dodana vodena otopina antibiotika ( $1 \%$ streptomicin sulfat, $20 \mathrm{ml} / \mathrm{l}$ ) nakon što su ohlađene na približno $55^{\circ} \mathrm{C}$. Za rast čistih kultura su se koristile hranjive podloge PDA (Potato Dextrose Agar, Difco) i MEA (Malt Extract Agar, Difco) pripremljene prema uputama proizvođača.

Listovi s vidljivim simptomima infekcije oprani su vodom iz slavine, zatim površinski sterilizirani uranjanjem u 0,04 $\%$ otopinu $\mathrm{NaOCl}$ u trajanju dvije minute, te tri puta isprani u sterilnoj vodi, nakon čega su ostavljeni da se u potpunosti osuše unutar laminarnog kabineta za rad u atmosferi čistog zraka (Themann i Werres 1999). Komadići listova veličine približno 3 x $3 \mathrm{~mm}$ uzimani su s ruba klorotičnog i/ ili nekrotičnog tkiva te uronjeni u hranjive podloge, tako da su čitavom površinom bili u dodiru s antibiotikom, čime se nastojao spriječiti razvoj bakterija. Ovako pripremljene Petrijeve zdjelice inkubirane su u tami na $21{ }^{\circ} \mathrm{C}$. Rast micelija praćen je svakodnevno tri tjedna uz redovito presađivanje, kako bi se dobile čiste kulture.

\section{Indukcija sporangija - Induction of sporangia}

Mikroskopskim pregledom dobivenih čistih kultura micelija utvrdilo se kako ne postoje morfološke značajke koje bi pomogle u identifikaciji, stoga je inducirana tvorba sporangija korištenjem tri različite nesterilne otopine tla. Kockice hranjivih podloga zajedno s pripadajućim micelijem površine približno $0,5 \mathrm{~cm}^{2}$ izrezane su s ruba kultura starih 4 do 7 dana te u sterilnim Petrijevim zdjelicama promjera $9 \mathrm{~cm}$ 
potopljene nesterilnom otopinom tla volumena $25 \mathrm{ml}$. Zatvorene Petrijeve zdjelice ostavljene su 24 do 48 sati na sobnoj temperaturi i prirodnom režimu svjetlosti, nakon čega se micelij promatrao i fotografirao pod svjetlosnim mikroskopom (Olympus BX41 s ugrađenom digitalnom kamerom Olympus DP20). Iako neki autori (Drenth i Sendall 2001) navode mogućnost korištenja destilirane vode u tu svrhu, u ranijim se istraživanjima za uzorke s istih lokacija nije pokazala učinkovitom (Hegol 2016), stoga su korištene nesterilne otopine tla koncentracija $1 \%, 1,5 \%$ te $5 \%$. Prve dvije otopine dobivene su miješanjem odgovarajuće mase tla (10, odnosno $15 \mathrm{~g})$ u $1 \mathrm{~L}$ ultračiste vode $(0,055 \mu \mathrm{S} / \mathrm{cm})$ na magnetskoj miješalici u trajanju od 4 sata, te je gornji vodeni sloj nakon što se tlo istaložilo filtriran gravitacijskom metodom kroz filter papir (Grade 388, Boeco Germany) (Drenth i Sendall 2001, Jeffers i Aldwinckle 1987). Za treću je otopinu $50 \mathrm{~g}$ tla potopljeno 1 litrom ultra čiste vode te ostavljeno da odstoji 48 sati, nakon čega je vodeni sloj bez taloga filtriran gravitacijskom metodom kroz filter papir (Grade 388, Boeco Germany) (Jung i sur. 1996). Otopine su čuvane u hladnjaku u tami na $4{ }^{\circ} \mathrm{C}$.

\section{Identifikacija vrsta molekularnim metodama - Species identification using molecular methods}

Za molekularne analize odabrana su po dva izolata morfoloških značajki karakterističnih za gljivama slične organizme sa svake istraživane lokacije. Izolacija DNA iz micelija vršena je prilagođenom metodom prema Allemann i sur. (1999) u Molekularno-biološkom laboratoriju Šumarskog fakulteta Sveučilišta u Zagrebu. Izolati su uzgojeni na MEA hranjivim podlogama na sterilnim celofanskim diskovima (Bio-Rad, Cellophane Membrane Backing) u tami na $21{ }^{\circ} \mathrm{C}$. Za izolaciju DNA je odvagano približno $50 \mathrm{mg}$ ovako uzgojenih micelija starih 7 dana za svaki odabrani izolat. Nakon mehaničke homogenizacije tkiva u tekućem dušiku $\left(\mathrm{N}_{2}\right)$ u mikroepruvetama, uzorcima je dodano 800 $\mu$ pufera za lizu (20 mM Tris, $200 \mathrm{mM} \mathrm{NaCl}, 2 \mathrm{mM}$ EDTA, $10 \%$ SDS, pH 8) i jednak volumen smjese fenol: kloroform: izoamilni alkohol u omjeru 25:24:1. Nakon centrifugiranja (Eppendorf AG 5804 R laboratorijska centrifuga) 10 minuta na 5000xg, vodena faza je otpipetirana u novu mikroepruvetu u koju je dodan jednak volumen otopine kloform:izoamilnog alkohola omjera 24:1. Nakon ponovnog centrifugiranja 10 minuta na 5000xg, vodena faza je otpipetirana u novu mikroepruvetu u koju je dodan jednak volumen izopropanola. Nakon centrifugiranja 20 minuta na $15000 \mathrm{xg}$ i $4{ }^{\circ} \mathrm{C}$ je supernatant dekantiran, a dobiveni talog DNA ispran s $500 \mu$ l ledeno-hladnog $70 \%$ etanola. Mikroepruvete su podvrgnute centrifugiranju 3 minute na $15000 x g$ i $4{ }^{\circ} \mathrm{C}$, nakon čega je etanol dekantiran, a talog DNA osušen približno 10 minuta na zraku te naposljetku otopljen u $50 \mu \mathrm{l}$ TE pufera ( $10 \mathrm{mM}$ Tris, $1 \mathrm{mM}$ EDTA).

Daljnja analiza dobivenih uzoraka DNA izvršena je u laboratoriju tvrtke InovaGen d.o.o. (Zagreb, Hrvatska), a obuhvaćala je lančanu reakciju polimerazom (PCR), kako bi se umnožila ciljana ITS regija te određivanje slijeda nukleotida (sekvence) navedene regije radi identifikacije vrsta. Pritom je za umnažanje ciljane sekvence korišten par početnica ITS4 (5'TCCTCCGCTTATTGATATGC3') i ITS6 (5'GAAGGTGAAGTCGTAACAAGG3') (White i sur. 1990, Cooke i sur. 2000) te protokol prema Grünwald i sur. (2011). Izolati su identificirani usporedbom dobivenih sekvenci s postojećima u bazi gena NCBI GenBank primjenom algoritma BLAST (Basic Local Alignment Search Tool).

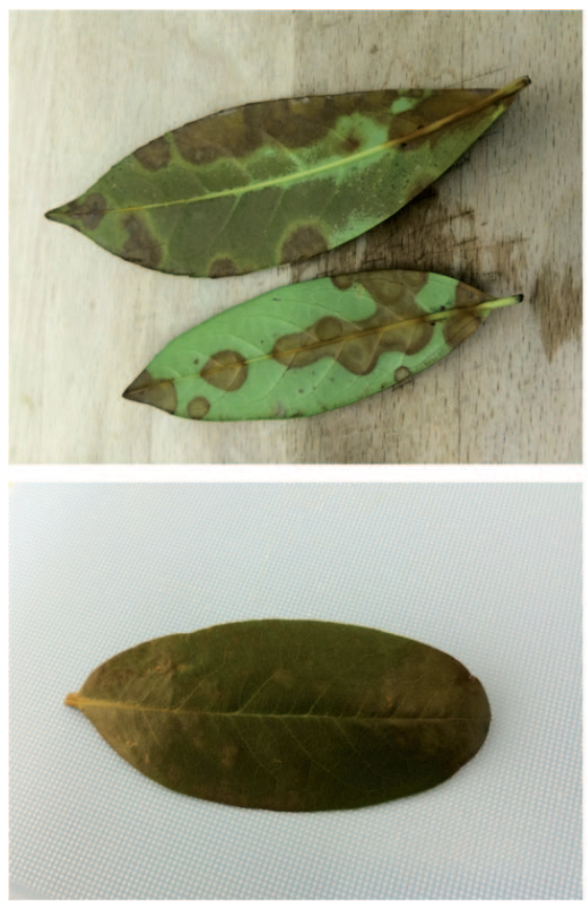

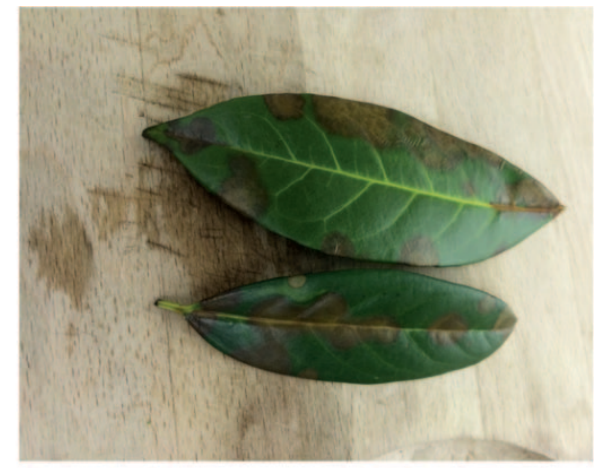

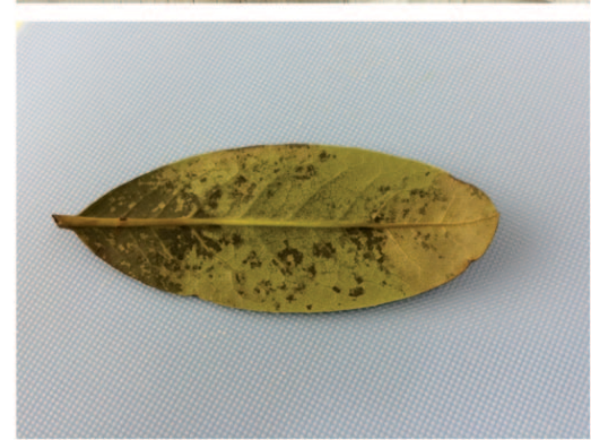

Slika 1. Simptomi na listovima Figure 1. Symptoms on leaves 
Slika 2. Neki od sporangija induciranih nesterilnim otopinama tla

Figure 2. Some of sporangia induced with non-sterile soil solutions
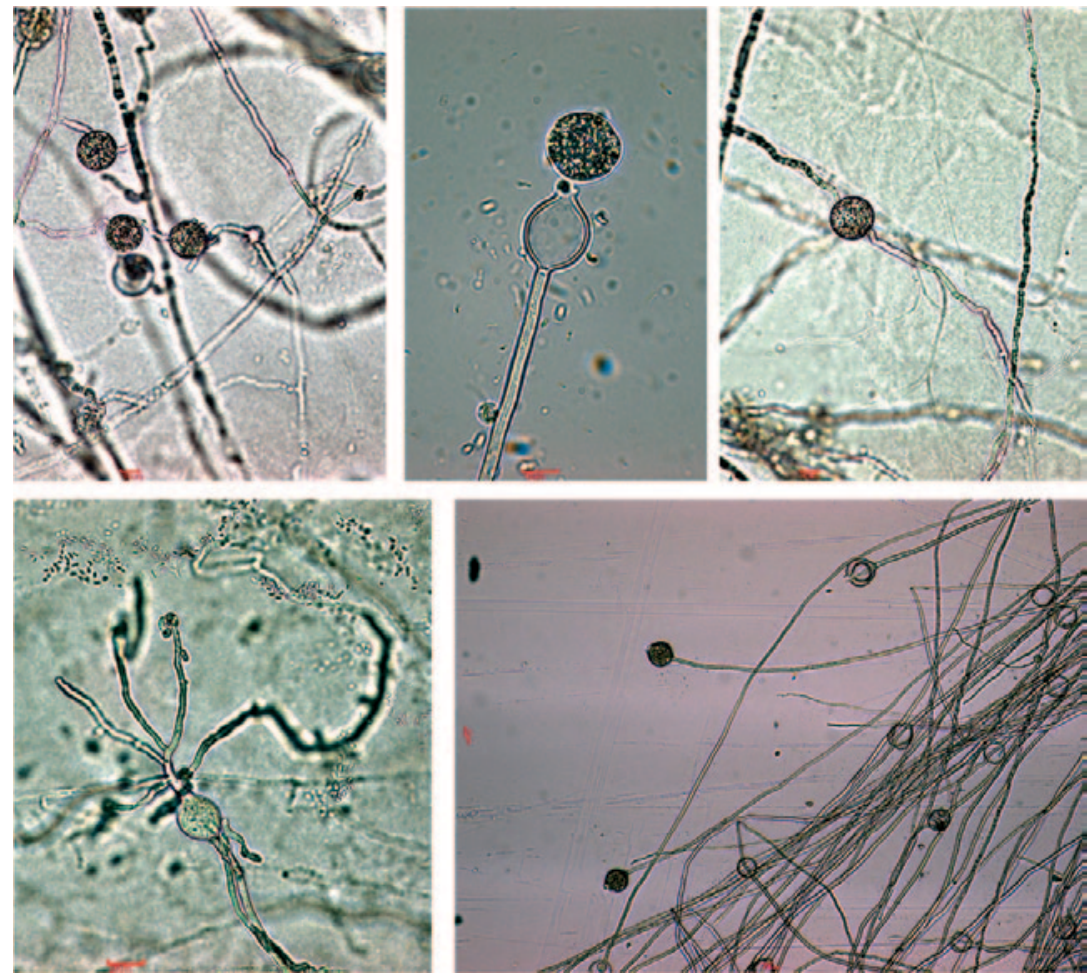

\section{REZULTATI}

\section{RESULTS}

\section{Uspješnost izolacije gljivama sličnih organizama iz tla - Success of fungus-like organisms isolation from soil}

$\mathrm{Na}$ listovima postavljenima na uzorke tla sakupljene u Dugom Selu, prvi su se simptomi razvili nakon 5 do 6 dana na svim uzorcima. Simptomi su bili vidlijivi u obliku okruglih i nepravilnih kloroza i smeđih i crnih nekroza na sredini i rubovima plojki te onih koje su se širile od vrha ili baze uz središnju žilu prema sredini plojke (slika 1). Miceliji karakteristični za gljivama slične organizme primijećeni su na svim uzorcima osim na listovima uzoraka broj 18 i 27 koji su sakupljeni oko stabala prve i druge zdravstvene kategorije. Kod svih osam dobivenih čistih kultura karakterističnih micelija uspješno je inducirana tvorba sporangija.

Listovi postavljeni na uzorcima tla iz Lipovljana počeli su pokazivati prve simptome nakon 4 do 5 dana na svim uzorcima, osim kod tla sakupljenog oko stabla broj 51 koje je na terenu procijenjeno kao stablo narušenog zdravstvenog stanja. Simptomi su bili jednaki onima zabilježenim na listovima uzoraka iz Dugog Sela. Miceliji s vegetativnim morfološkim značajkama karakterističnim za gljivama slične organizme razvili su se na osam uzoraka listova, odnosno nisu razvijeni kod listova uzorka broj 56 (stablo narušenog zdrav. stanja). Tvorba sporangija uspješno je inducirana na svih osam karakterističnih micelija.

Prvi su se simptomi na listovima postavljenim na uzorcima tla iz Novske pojavili šest dana nakon potapanja tla, osim kod uzorka 77, gdje su se pojavili nakon 10 dana. Razvijeni su kod svih uzoraka te su bili jednaki onima primijećenim na listovima uzoraka tla s prethodne dvije lokacije. Rast micelija morfološki karakterističnog za gljivama slične organizme utvrđen je kod listova gotovo svih uzoraka, s iznimkom uzoraka broj 78 (odumiruće stablo) i 89 (stablo narušenog zdrav. stanja). Od ukupno osam dobivenih čistih kultura karakterističnih micelija, tvorba sporangija je uspješno inducirana kod njih sedam. Kod izolata vezanog uz uzorak broj 86 (zdravo stablo) nakon potapanja micelija nesterilnom otopinom tla nisu primijećene nikakve generativne tvorbe koje bi upućivale na gljivama sličan organizam.

\section{Identifikacija vrsta - Species identification}

Za molekularne analize odabrano je ukupno šest morfološki karakterističnih izolata, po dva sa svake istraživane lokacije. Od toga je pet izolata uspješno razvilo sporangije (slika 2), dok je izolat uzorka broj 86 razvio micelij morfološki karakterističan za gljivama slične organizme, ali bez generativnih tvorbi, zbog čega je posebno odabran za identifikaciju molekularnim metodama.

DNA zadovoljavajućih prinosa i čistoće izolirana je iz micelija svih odabranih izolata. Iako se odabrani par početnica pokazao odgovarajućim za umnažanje ciljane regije lančanom reakcijom polimerazom, jer su za sve uzorke izolirane DNA dobiveni specifični produkti veličine približno 800-900 bp, sekvenciranje početnicom ITS6 nije rezultiralo dovoljno kvalitetnim sekvencama pri istim uvjetima is jednakim reakcijskim komponentama kao sekvenciranje početnicom ITS4. Stoga su za identifikaciju vrsta korištene dobivene sekvence iz jednog smjera duljine 641 do 680 bp. Korištenjem 
Tablica 2. Identificirane vrste gljivama sličnih organizama Table 2. Identified species of fungus-like organisms

$\begin{array}{lcccc}\begin{array}{l}\text { Oznaka stabla/ } \\ \text { uzorka tla } \\ \begin{array}{l}\text { Tree mark/soil } \\ \text { sample mark }\end{array}\end{array} & \begin{array}{c}\text { Identifikacijski broj } \\ \text { sekvence } \\ \text { Accession number }\end{array} & \begin{array}{c}\text { Vrsta najveće podudarnosti } \\ \text { sekvence prema BLAST algoritmu } \\ \text { Closest match in BLAST }\end{array} & \begin{array}{c}\text { Identifikacijski broj podudarajuće } \\ \text { sekvence u NCBI GenBank } \\ \text { Accession number of the matched } \\ \text { sequence }\end{array} & \begin{array}{c}\text { Podudarnost } \\ \text { sekvenci \% } \\ \text { Identity \% }\end{array} \\ 4 & \text { KY708964 } & \text { Phytopythium citrinum } & \text { AY197328.1 } & 99 \\ 6 & \text { KY708965 } & \text { Phytopythium citrinum } & \text { AY197328.1 } & 99 \\ 43 & \text { KY708963 } & \text { Phytopythium citrinum } & \text { AY197328.1 } & 99 \\ 54 & \text { KY708962 } & \text { Phytopythium litorale } & \text { KU961901.1 } & 95 \\ 76 & \text { KY708961 } & \text { Pythium lutarium } & \text { KU209134.1 } & 99 \\ 86 & \text { KY707823 } & \text { Pythium anandrum } & \text { AY598650.3 } & 99\end{array}$

inačice algoritma Megablast za sekvence velike sličnosti ( $h i$ ghly similar sequences) za svih šest sekvenci pronađena je podudarnost $s$ već postojećima u NCBI GenBank bazi.

Rezultati nisu potvrdili prisutnost patogenih vrsta roda Phytophthora, već su pokazali da identificirane vrste pripadaju rodovima Pythium i Phytopythium (tablica 2). Tri izolata dobivena iz tla oko odumirućih stabala su identificirana su kao vrsta Phytopythium citrinum (B. Paul) Abad, De Cock, Bala, Robideau, Lodhi \& Lévesque, dok su preostala tri koja su izolirana iz tla oko zdravih stabala identificirana kao tri različite vrste.

\section{RASPRAVA I ZAKLJUČCI DISCUSSION AND CONCLUSIONS}

Do sada su u Hrvatskoj od gljivama sličnih organizama prisutnih u tlu istraživane jedino vrste roda Phytophthora, koje su potvrđene u tlima bukovih (Fagus sylvatica L.) sastojina na području Bjelovara te u tlima kultura topola (Populus $\mathrm{x}$ euroamericana) na području Osijeka i Valpova (Pernek i sur. 2011). Kako se vrste navedenog roda smatraju jednim od glavnih uzročnika odumiranja šumskog drveća u Europi (Jung i sur. 2013, Jankowiak i sur. 2014), ovim se istraživanjem nastojalo utvrditi mogućnost njihova sudjelovanja u odumiranju poljskog jasena u posavskim nizinskim šumama Republike Hrvatske. Iako su preliminarna istraživanja na uzorcima tla pomoću terenskih dijagnostičkih testova (eng. Pocket diagnostic test, Abingdon Health Ltd., UK) provedena u srpnju 2016. godine ukazala na prisutnost vrsta roda Phytophthora (Hegol 2016) u sastojinama poljskog jasena, iz uzoraka tla sakupljenih na istim lokacijama te analiziranih u ovom istraživanju su indirektnim metodama izolacije potvrđene isključivo vrste rodova Pythium i Phytopythium. Navedena činjenica ne umanjuje nužno vjerodostojnost terenskih testera, koji se i dalje mogu koristiti kao inicijalni pokazatelji prisutnosti vrsta roda Phytophthora, već može biti i posljedica manje zastupljenosti vrsta navedenog roda u tlu u odnosu na druge predstavnike gljivama sličnih organizama koji u kulturama micelija uzgojenim in vitro pokazuju brži rast te mogu znatno otežati identifikaciju sporije rastućih vrsta (Balcì i Halmschlager 2003a).
Miceliji gljivama sličnih organizama su indirektnom metodom izolirani iz 24 od ukupno 30 analiziranih uzoraka tla, što upućuje na njihovu visoku zastupljenost u ovoj ekološkoj niši. Navedeni podatak ne iznenađuje s obzirom na činjenicu da se gljivama slični organizmi uglavnom šire zoosporama pokretljivim u vodi, a istraživane lokacije obuhvaćaju često plavljena staništa. Molekularne analize odabranih šest izolata su rezultirale identifikacijom čak četiri različite vrste dvaju rodova: Pythium i Phytopythium, ukazujući na visoku raznolikost ovih organizama u tlu. Pretpostavka je kako je zbog ograničenog broja uzoraka stvarna bioraznolikost gljivama sličnih organizama u tlu sastojina poljskog jasena veća od dobivene ovim istraživanjem.

Tri odabrana izolata dobivena iz uzoraka tla sakupljenih oko odumirućih stabala identificirana su kao Phytopythium citrinum, koja je do uspostave novog roda (Bala i sur. 2010, de Cock i sur. 2015) bila poznata kao Pythium citrinum B. Paul, a pokazala se učestalom i u tlima sastojina hrasta lužnjaka narušenog zdravstvenog stanja te riječnim tokovima u Poljskoj (Jankowiak i sur. 2015, Matsiakh i sur. 2016). Vrste Pythium lutarium Ali-Shtayeh te Phytopythium litorale (Nechw.) Abad, De Cock, Bala, Robideau, Lodhi \& Lévesque, prije poznata kao Pythium litorale Nechw., koje su izolirane iz uzoraka tla sakupljenog oko zdravih stabala, do sada nisu potvrđene u tlima šumskih sastojina u sličnim istraživanjima provedenim u drugim europskim državama, već jedino u vodenim tokovima u Poljskoj (Matsiakh i sur. 2016). S obzirom da su ostala istraživanja obuhvatila isključivo sastojine hrasta lužnjaka, može se zaključiti kako vrste posjeduju sklonost prema određenim staništima i/ili šumskim zajednicama, iako su za potvrdu takvog zaključka potrebni dodatni dokazi, odnosno ispitivanja na većem broju uzoraka. Vrsta Pythium anandrum Drechsler koja je potvrđena u uzorku tla sakupljenom oko zdravog stabla poljskog jasena, u većini se europskih istraživanja provedenih u lužnjakovim sastojinama opisuje kao najobilnija vrsta roda Pythium u tlu s visokom učestalošću izolacije (Jung i sur. 2000, Jönsson i sur. 2003, Balcì i Halmschlager 2003a, Balcì i Halmschlager 2003b, Jankowiak i sur. 2015), a navodi se i kao mogući patogen hrasta kitnjaka (Quercus petraea / Matt./ Liebl.) u Turskoj na temelju visoke zastupljenosti u tlima odumirućih sastojina i razvoja nekroza u testovima 
patogenosti provedenim na trogodišnjim sadnicama (Akilli i sur. 2013), te kao uzročnik odumiranja korijena na sadnicama obične smreke (Picea abies L. Karst) u rasadnicima u Norveškoj (Børja i sur. 2015).

Identifikacijom vrsta gljivama sličnih organizama u tlu odumirućih sastojina poljskog jasena u posavskim nizinskim šumama nije potvrđena prisutnost roda Phytophthora na istraživanim lokacijama, zbog čega će do daljnjih istraživanja ove vrste biti isključene kao jedan od mogućih čimbenika u kumulativnom i sinergijskom djelovanju na odumiranje poljskog jasena. Ulogu identificiranih vrsta rodova Pythium i Phytopythium u tlu tek treba dodatno razjasniti. Za sada nema sigurne potvrde o njihovoj povezanosti sa zdravstvenim stanjem šumskih sastojina, iako su poznate kao patogeni određenih poljoprivrednih kultura i šumskih sadnica u rasadnicima, te su vrlo česte u tlima odumirućih sastojina zajedno s vrstama roda Phytophthora (Jankowiak i sur. 2015).

\section{ZAHVALA}

\section{ACKNOWLEDGEMENT}

Provedena istraživanja financirana su sredstvima Hrvatske zaklade za znanost (HRZZ) u sklopu projekta ,The role of biotic agents on vitality of narrow-leaved ash (Fraxinus angustifolia Vahl) in Croatian floodplain forests" FRAXINPRO (IP-11-2013).

\section{LITERATURA}

\section{REFERENCES}

- Akilli, S., C. U. Serce, Y. Z. Katircioglu, S. Maden, 2013: Does Pythium anandrum contribute to the dieback of sessile oak (Quercus petraea) in Turkey?, For. Path., 43: 505-508.

- Akilli, S., Ç. Ulubaş Serçe, Y. Z. Katırcıoğlu, S. Maden, 2013: Phytophthora dieback on narrow leaved ash in the Black Sea region of Turkey, For. Path., 43: 252-256.

- Allemann C, P., Hoegger, U. Heiniger, D. Rigling, 1999: Genetic variation of Cryphonectria hypoviruses (CHV1) in Europe, assessed using restriction fragment length polymorphism (RFLP) markers, Molecular Ecology, 8: 843-854.

- Bala, K, G. P. Robideau, C. A. Levésque, A. W. de Cook, Z. G. Abad, A. M. Lodhi, S. Shahzad, A. Ghaffar, M. D. Coffey, 2010: Phytopythium Abad, de Cock, Bala, Robideau, Lodhi \& Lévesque, gen. nov. and Phytopythium sindhum Lodhi, Shahzad \& Lévesque, sp. nov, Persoonia, 24: 136-137.

- Balci, Y., E. Halmschlager, 2003a: Incidence of Phytophthora species in oak forests in Austria and their possible involvement in oak decline, For. Pathol., 33: 157-174.

- Balcì, Y., E. Halmschlager, 2003b: Phytophthora species in oak ecosystems in Turkey and their association with declining oak trees, Plant Pathol., 52: 694-702.

- Børja, I., N. E. Nagy, M. B. Brurberg, L. Sundheim, M. L. Herrero, 2015: Pathogenicity of Norwegian isolates of Pythium undulatum and Pythium anandrum on Norway spruce seedlings, Agarica, 36: 5-10.

- Campbell, W.A., F. F. Hendrix, W. M. Powell, 1972: Pythium and nematode species implicated in root rot, Tree Planters' Notes, 23. (1): 5-7.
- Cooke, D. E. L., A. Drenth, J. M. Duncan, G. Wagels, C. M. Brasier, 2000: A molecular phylogeny of Phytophthora and related oomycetes, Fungal Genet.Biol., 30: 17-32.

- de Cock, A. W., A. M. Lodhi, T. L. Rintoul, K. Bala, G. P. Robideau, Z. G. Abad, M. D. Coffey, S. Shahzad, C. A. Lévesque, 2015: Phytopythium: molecular phylogeny and systematics, Persoonia, 34: 25-39.

- Diminić, D., 2015: Nova bolest jasena (Fraxinus spp.) u Hrvatskoj, U: S. Matić, F. Tomić, I. Anić (ur.), Proizvodnja hrane i šumarstvo - temelj razvoja istočne Hrvatske, Hrvatska akademija znanosti i umjetnosti, 363-373., Zagreb

- Drenth, A., B. Sendall, 2001: Practical guide to detection and identification of Phytophthora, CRC for Tropical Plant Protection, 1-41., Brisbane

- Grünwald, N. J., F. N. Martin, M. M. Larsen, C. M. Press, Sullivan, M. D. Coffey, E. M. Hansen, J. L. Parke, 2011: PhytophthoraID.org: A sequence-based Phytophthora identification tool, Plant Disease, 95. (3): 337-342.

- Hauptman, T., N. Ogris, D. Jurc, 2012: Ash dieback in Slovenia, Forstschutz Aktuell, 55: 62-63.

- Hegol, M., 2016: Izolacija vrsta roda Phytophthora iz tla indirektnom metodom. Diplomski rad, Šumarski fakultet Sveučilišta u Zagrebu, 1-37.

- Jankovsky, L., O. Holdenrieder, 2009: Chalara fraxinea - ash dieback in the Chech Republic, Plant Protection Science, 45. (2): 74-78.

- Jankowiak, R., H. Stępniewska, P. Bilański, 2015: Notes on some Phytopythium and Pythium species occurring in oak forests in southern Poland, Acta Mycol., 50. (1): 1052.

- Jankowiak, R., H. Stepniewska, P. Bilanski, M. Kolarik, 2014: Occurrence of Phytophthora plurivora and other Phytophthora species in oak forests of southern Poland and their association with site conditions and the health status of trees, Folia Microbiologica, 59. (6): 531-542., Prague

- Jeffers, S. N., 2007: Identifying species of Phytophthora, Clemson University South Carolina, 1-9., Clemson

- Jeffers, S. N., H. S., Aldwinckle, 1987: Enhancing Detection of Phytophthora cactorum in Naturally Infested Soil, Phytopathology, 77: 1475-1482.

- Jönsson, U., L. Lundberg, K. Sonesson, T. Jung, 2003: First records of soilborne Phytopthora species in Swedish oak forests, For. Pathol., 33: 175-179.

- Jung, T., A. M. Vettraino, T. Cech, A. Vannini, 2013: The Impact of Invasive Phytophthora Species on European Forests, Phytophthora: a global perspective, CAB International, 146-158., Oxfordshire

- Jung, T., H. Blaschke, P. Neumann, 1996: Isolation, identification and pathogenicity of Phytophthora species from declining oak stands, Europ. Jour. of For. Path., 26: 253-272., Berlin

- Jung, T., H. Blaschke, W. O $\beta$ wald, 2000: Involvement of soilborne Phythophthora species in central European oak decline and the effect of site factors on the disease. Plant Pathol., 49: 706-718.

- Kirisits, T., M. Matlakova, S. Mottinger-Kroupa, E. Halmschlager, F. Lakatos, 2010: Chalara fraxinea associated with dieback of narrow-leaved ash (Fraxinus angustifolia), Plant Path., 59. (2): 411-411.

- Lévesque, C. A, A. W. de Cock, 2004: Molecular phylogeny and taxonomy of the genus Pythium. Mycol Res., 108: 1363-1383.

- Margulis, L., K. V. Schwartz, 2000: Five kingdoms: an illustrated guide to the phyla of life on earth, W. H. Freeman and Co., 376 str., New York 
- Matsiakh, I., T. Oszako, V. Kramarets, J. A. Nowakowska, 2016: Phytophthora and Pythium Species Detected in Rivers of the Polish-Ukrainian Border Areas, Balt. For., 22. (2): 230-238.

- Milotić, M., J. Kranjec, D. Diminić, 2016: Current status of ash dieback disease Hymenoscyphus fraxineus in Croatia, In: I. Radojčić Redovniković, K. Radošević, T. Jakovljević, R. Stojaković, V. Gaurina Srček, D. Erdec Hendrih (ed.), Natural resources, green technology \& sustainable development GREEN/2, Faculty of Food Technology and Biotechnology of Zagreb University, 124-124., Zagreb

- Orlikowski, L. B., M. Ptaszek, A. Rodziewicz, J. Nechwatal, K. Thinggaard, T. Jung, 2011: Phytophthora root and collar rot of mature Fraxinus excelsior in forest stands in Poland and Denmark, For. Path., 41: 510-519.

- Pernek, M., M. Županić, D. Diminić, T. Cech, 2011: Vrste roda Phytophthora na bukvi i topolama u Hrvatskoj, Šum. List, 13: 130-137., Zagreb

- Potočić, N., I. Seletković, T. Jakovljević, H. Marjanović, K. Indir, J. Medak, N. Lacković, 2016: Oštećenost šumskih ekosustava Republike Hrvatske - izvješće za 2015. godinu, Nacionalni koordi- nacijski centar za procjenu i motrenje utjecaja atmosferskog onečišćenja i drugih čimbenika na šumske ekosustave, Hrvatski šumarski institut, 4-14., Jastrebarsko

- Themann, K., S. Werres, 1999: Baiting of Phytophthora sp. with the Rhododendron leaf test, In: E. M. Hansen, Sutton, W. (ed.), First International Meeting on Phytophthoras in Forest and Wildland Ecosystems, Oregon State University, 141-144., Oregon

- Vettraino, A. M., G. Natili, N. Anselmi, A. Vannini, 1999: Recent advances in studies on Phytophthora species associated with Castanea sativa and Quercus cerris in Italy, In: E. M. Hansen, Sutton, W. (ed.), First International Meeting on Phytophthoras in Forest and Wildland Ecosystems, Oregon State University, 34-36., Oregon

- Vettraino, A. M., G. P. Barzanti, M. C. Bianco, A. Ragazzi, P. Capretti, E. Paoletti, 2002: Occurrence of Phytophthora species in oak stands in Italy and their association with declining oak trees, For. Pathol., 32: 19-28.

- White, T. J., T. Bruns, S. Lee, J. Taylor, 1990: Amplification and direct sequencing of fungal ribosomal RNA genes for phylogenetics, PCR protocols: a Guide to Methods and Applications, Academic Press, 315-322., San Diego

\section{Summary}

Narrow-leaved ash (Fraxinus angustifolia Vahl), ecologically and economically very important species of Croatian lowland forests, has been showing more prominent symptoms of dieback in the past few years. Research conducted so far has confirmed presence of the pathogenic fungus Hymenoscyphus fraxineus Baral, Queloz \& Hosoya in the crowns and stems of the trees showing the symptoms of dieback at several locations in Croatia (Diminić 2015, Milotić et al. 2016). Since forest dieback is usually a consequence of multiple abiotic and biotic factors, research to find causes often encompass not just the above-ground parts of stands, but also the root systems and soil, where fungal-like organisms such as Phytophthora species are considered to be an important biotic factor responsible for tree mortality. The goal of this research was to detect fungus-like organisms in the soil of declining narrow-leaved ash stands in order to confirm or reject the hypothesis that pathogenic Phytophthora species have a potential role in the dieback and also to expand the knowledge about fungus-like organisms' diversity in Croatian forest soils.

Total of 30 soil samples were collected from three forest management units (ten from each) in declining narrow-leaved ash stands, around the stems of trees of different health status according to Jankowiak et al. (2014). Fungus-like organisms were isolated using the soil baiting method according to Themann and Werres (1999), with Rhododendron catawbiense Michx. and Prunus laurocerasus L. leaves used as baits. Pure mycelia cultures showing vegetative morphological features characteristic for fungal-like organisms were obtained from 24 soil samples. To confirm this, sporangia production was induced in these isolates by flooding agar discs taken from 4-7 days old colonies with three different non-sterile soil extracts for each $(1 \%, 1,5 \%, 5 \%)$. Sporangia were successfully induced in all isolates except one, which was chosen for the species identification using molecular methods together with five others (two isolates from each location). Genomic DNA was isolated using modified phenol-chloroform method according to Allemann et al. (1999). Amplification of internal transcribed spacers (ITS1 and ITS2) and 5.8 subunit of nuclear ITS rDNA region was conducted using the ITS4/ ITS6 primer set, with reaction mixture and PCR protocol as in Grünwald et al. (2011). Amplification, PCR product purification and sequencing were conducted at InovaGen Ltd. (Zagreb, Croatia). All three isolates obtained from soil sampled around declining trees were identified as Phytopythium citrinum (B. Paul) Abad, De Cock, Bala, Robideau, Lodhi \& Lévesque, and other three obtained from soil sampled around healthy trees were identified as Pythium lutarium Ali-Shtayeh, Pythium anandrum Drechsler and Phytopythium litorale Nechw. Presence of Phytophthora species in the soil of declining narrow-leaved ash stands wasn't confirmed at the investigated locations, excluding them as one of the potential causative agents of narrow-leaved ash dieback in Croatia until further research is conducted. Although the Pythium and Phytopythium species were often isolated from the soil of declining forest stands and are known pathogens of seedling in forest nurseries, their possible role in dieback of narrow-leaved ash has yet to be determined. 